\title{
Protocol
}

\section{The Basic Polymerase Chain Reaction (PCR)}

\author{
Michael R. Green and Joseph Sambrook
}

This protocol describes the reagents and procedures required to amplify a segment of double-stranded DNA in a chain reaction catalyzed by a thermostable DNA polymerase. It is the foundation for all subsequent variations of the polymerase chain reaction (PCR).

\section{MATERIALS}

Reagents
It is essential that you consult the appropriate Material Safety Data Sheets and your institution's Environmental Health and Safety Office for proper handling of equipment and hazardous materials used in this protocol.

Amplification buffer $(10 \times)$ containing $\mathrm{MgCl}_{2}$ (as supplied by the Taq polymerase manufacturer) Bystander DNA

Bystander DNA does not contain target sequences. It should resemble the template DNA in all other respects: complexity, size, and concentration.

Chloroform (optional; see Step 6)

dNTP mix (all four dNTPs, 20 mm each; pH 8.0)

Ethidium bromide (optional; see Step 5)

Gel, polyacrylamide or agarose (see Step 5)

Primers:

Forward primer $\left(20 \mu \mathrm{M}\right.$, in $\left.\mathrm{H}_{2} \mathrm{O}\right)$

Reverse primer $\left(20 \mu \mathrm{M}\right.$, in $\left.\mathrm{H}_{2} \mathrm{O}\right)$

Each primer should be 20-30 nt in length and contain approximately equal numbers of the four bases, with a balanced distribution of $G$ and $C$ residues and a low propensity to form stable secondary structures. As discussed below, restriction sites can be incorporated into the design of primers. Amplification using primers of this type generates DNAs that carry restriction sites at both ends, which can facilitate cloning.

Oligonucleotide primers synthesized on an automated DNA synthesizer can generally be used in standard PCR without further purification. However, amplification of single-copy sequences from mammalian genomic templates is often more efficient if the oligonucleotide primers are purified by chromatography on commercially available resins or by denaturing polyacrylamide gel electrophoresis.

Use the following formula to calculate the molecular mass of the oligonucleotides:

$$
M_{r}=(\mathrm{C} \times 289)+(\mathrm{A} \times 313)+(\mathrm{T} \times 304)+(\mathrm{G} \times 329),
$$

where $\mathrm{C}$ is the number of $\mathrm{C}$ residues in the oligonucleotide, $\mathrm{A}$ is the number of $\mathrm{A}$ residues, $\mathrm{T}$ is the number of $T$ residues, and $\mathrm{G}$ is the number of $\mathrm{G}$ residues. The molecular mass of a 20-mer will be $\sim 6000$ Da; 100 pmol of the oligonucleotide will be equivalent to $\sim 0.6 \mu \mathrm{g}$.

From the Molecular Cloning collection, edited by Michael R. Green and Joseph Sambrook.

(c) 2018 Cold Spring Harbor Laboratory Press

Cite this protocol as Cold Spring Harb Protoc; doi:10.1101/pdb.prot095117 
SYBR Gold (optional; see Step 5)

Template DNA (e.g., mammalian genomic DNA [100 $\mu \mathrm{g} / \mathrm{mL}]$, yeast genomic DNA [1 $\mu \mathrm{g} / \mathrm{mL}]$, bacterial genomic DNA [0.1 $\mu \mathrm{g} / \mathrm{mL}]$, plasmid DNA [1-5 ng/mL], in $10 \mathrm{~mm}$ Tris-Cl [pH 7.6] containing $<0.1$ mM EDTA)

Thermostable DNA polymerase (e.g., Agilent, Thermo Fisher, etc.)

Taq DNA polymerase is the standard and appropriate enzyme for the amplification stage of most forms of PCR. However, where elongation from 3'-mismatched primers is suspected, a thermostable DNA polymerase with $3^{\prime} \rightarrow 5^{\prime}$ proofreading activity might be preferable (Chiang et al. 1993).

Taq DNA polymerase is supplied in a storage buffer containing 50\% glycerol. Because this solution is very viscous and difficult to pipette accurately, the best method is to centrifuge the tube containing the enzyme at maximum speed for $10 \mathrm{sec}$ at $4^{\circ} \mathrm{C}$ in a microcentrifuge and then to withdraw the required amount of enzyme using a positive-displacement pipette.

Water, PCR-grade

PCR-grade water is free of ions, salts, and nucleases and has a balanced pH. It is commercially available from a number of suppliers.

To reduce the chance of contamination with exogenous DNAs, prepare and use a special set of reagents and solutions for PCR only.

\section{Equipment}

Barrier tips (for automatic micropipetting device) (e.g., ART Barrier Tips [Thermo Fisher]).

Automatic micropipetting devices equipped with barrier tips should be used to assemble the components of PCRs. Disposable barrier tips are fitted with a hydrophobic barrier to prevent the accidental passage of liquids into a micropipetting device. This arrangement reduces the potential for cross-contamination of PCR and DNA samples.

Gel electrophoresis equipment (for polyacrylamide or agarose gels)

Microcentrifuge tubes, $0.5 \mathrm{~mL}$, thin-walled (optional; see Step 1)

Thin-walled plastic tubes that fit snugly in the block of the thermal cycler are used for amplification. Their use facilitates heat transfer and greatly reduces much of the time lag in reaching programmed temperatures.

Microtiter plates (optional; see Step 1)

Mineral oil (optional; see Step 3)

Paraffin wax (optional; see Step 3)

Pipette, positive-displacement

Positive-displacement pipetting, in which the piston is in direct contact with the liquid, is used for accurate transfer of high-viscosity liquids.

Thermal cycler

A number of programmable thermal cyclers marketed by different commercial companies (e.g., Mastercycler [Eppendorf], PTC-100 [MJ Research]) are licensed by PerkinElmer for use in PCR. The choice among these instruments depends on the investigator's inclination, the available budget, and the range of uses to which the machine will be put. Before purchasing a thermal cycler, we recommend soliciting as many opinions as possible to discover the advantages and disadvantages of different machines.

Bake all glassware for $6 \mathrm{~h}$ at $150^{\circ} \mathrm{C}$, and autoclave all plasticware.

\section{METHOD}

The standard reaction conditions for PCR are: $1.5 \mathrm{~mm} \mathrm{Mg}{ }^{2+}, 50 \mathrm{~mm} \mathrm{KCl}, 0.4 \mathrm{~mm}$ dNTPS, $1 \mu \mathrm{m}$ of each of the primers, 1-5 units DNA polymerase, and $1 \mathrm{pg}$ to $1 \mu \mathrm{g}$ of template DNA. The $\mathrm{pH}$ of the reaction buffer should be 8.3 when measured at $25^{\circ} \mathrm{C}$. Because of the high temperature dependence of the $p K_{a}$ of Tris, the $\mathrm{pH}$ of the reaction will drop to $\sim 7.2$ at $72^{\circ} \mathrm{C}$ (Good et al. 1966; Ferguson et al. 1980). The amount of template DNA required varies according to the complexity of its sequence. In the case of mammalian DNA, up to $1.0 \mu \mathrm{g}$ is used per reaction. Typical amounts of yeast, bacterial, and plasmid DNAs used per reaction are $10 \mathrm{ng}, 1 \mathrm{ng}$, and $10 \mathrm{pg}$, respectively.

1. In a sterile $0.5-\mathrm{mL}$ microcentrifuge tube, amplification tube, or the well of a sterile microtiter plate, mix in the following order: 
M.R. Green and J. Sambrook

Amplification buffer $(10 \times)$

dNTP mix (20 mm each, pH 8.0)

Forward primer $(20 \mu \mathrm{M})$

Reverse primer $(20 \mu \mathrm{M})$

Thermostable DNA polymerase ( $1-5$ units $/ \mu \mathrm{L})$

Template DNA

$\mathrm{H}_{2} \mathrm{O}$

$$
\begin{array}{r}
5 \mu \mathrm{L} \\
1 \mu \mathrm{L} \\
2.5 \mu \mathrm{L} \\
2.5 \mu \mathrm{L} \\
1-2 \text { units } \\
5-10 \mu \mathrm{L}
\end{array}
$$

\begin{tabular}{|c|c|c|c|c|}
\hline & Bystander DNA & Template DNA ${ }^{\mathrm{a}}$ & Target $\mathrm{DNA}^{\mathrm{b}}$ & Specific primers $^{\mathrm{c}}$ \\
\hline \multicolumn{5}{|c|}{ Positive controls } \\
\hline 1 & + & - & + & + \\
\hline 2 & - & - & + & + \\
\hline \multicolumn{5}{|c|}{ Negative controls } \\
\hline 3 & - & - & - & + \\
\hline 4 & + & - & - & + \\
\hline
\end{tabular}

to a final volume of $50 \mu \mathrm{L}$

2. Prepare positive and negative controls, as detailed below:

Positive controls are required to monitor the efficiency of the $P C R$, whereas negative controls are required to detect contamination with DNAs that contain the target sequence.

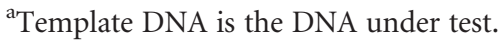

${ }^{b}$ Target DNA contains the target sequence. It can be a recombinant DNA clone, a purified DNA fragment, or a sample of genomic DNA. It should be added to the positive control at concentrations equivalent to those expected in the template DNA. It is often necessary to prepare a series of positive controls containing different amounts of target DNA spanning the amount predicted in the template DNA. An appropriate dilution of the target sequence should be prepared ahead of time in an area of the laboratory different from that used for the preparation of other PCR reagents. This precaution reduces the risk of contaminating equipment and plasticware in the area of the laboratory set aside for PCRs.

${ }^{\mathrm{c} S}$ pecific primers are oligonucleotide primers specific for the segment of target DNA.

3. If the thermal cycler is not fitted with a heated lid, overlay the reaction mixtures with 1 drop $(\sim 50$ $\mu \mathrm{L}$ ) of light mineral oil. Alternatively, if using a hot start protocol (see Protocol: Hot Start Polymerase Chain Reaction (PCR) [Green and Sambrook 2018a]), place a bead of wax into the tube. Place the tubes or the microtiter plate in the thermal cycler.

This prevents evaporation of liquid from the reaction mixture during PCR. Paraffin wax also maintains separation between components (e.g., primer and template) until the reaction mixture is heated. This separation prevents nonspecific binding of primers during the initial phase of the reaction.

4. Amplify the nucleic acids using the denaturation, annealing, and polymerization times and temperatures listed below:

\begin{tabular}{llll}
\hline Cycle number & Denaturation & Annealing & Polymerization \\
\hline $1-30$ & $30 \mathrm{sec}$ at $94^{\circ} \mathrm{C}$ & $30 \mathrm{sec}$ at $55^{\circ} \mathrm{C}$ & $1 \mathrm{~min}$ at $72^{\circ} \mathrm{C}$ \\
Last cycle & $1 \mathrm{~min}$ at $94^{\circ} \mathrm{C}$ & $30 \sec$ at $55^{\circ} \mathrm{C}$ & $1 \mathrm{~min}$ at $72^{\circ} \mathrm{C}$ \\
\hline
\end{tabular}

Normally, polymerization is performed for 1 min for every $1000 \mathrm{bp}$ of length of the target DNA. Times and temperatures might need to be adapted to suit the specific thermal cycler used and/or reaction volumes.

Most thermal cyclers have an end routine in which the amplified samples are incubated at $4^{\circ} \mathrm{C}$ until they are removed from the machine. Samples can be left overnight at this temperature, but should be stored thereafter at $-20^{\circ} \mathrm{C}$.

5. Analyze a sample $(5-10 \mu \mathrm{L})$ from the test reaction mixture and each of the four control reactions by electrophoresis through an agarose or polyacrylamide gel. Be sure to include DNA markers of an appropriate size. Stain the gel with ethidium bromide or SYBR Gold to visualize the DNA. 
A successful amplification reaction should yield a readily visible DNA fragment of the expected size. The identity of the band can be confirmed by DNA sequencing, Southern hybridization, and/or restriction mapping. Lanes of the gel containing samples of the two positive controls and the template DNA under test should contain a prominent band of DNA of the appropriate molecular mass. This band should be absent from the lanes containing samples of the negative controls.

If necessary, the yield of desired product can be improved by setting up a second round of amplification using another pair of primers that bind to sequences within the amplified segment of target DNA. After this second round of nested amplification, almost all the product detected by ethidium bromide staining contains the desired segment of DNA. See also Box 1.

When setting up PCRs for the first time with new template DNA, new primers, or a new preparation of thermostable DNA polymerase, amplification will generally be less than optimal. Fine-tuning of the reaction is usually required to suppress nonspecific amplification and/or to enhance the yield of amplified DNA. See Troubleshooting.

6. If mineral oil was used to overlay the reaction (Step 3), remove the oil from the sample by extraction with $150 \mu \mathrm{L}$ of chloroform.

The aqueous phase, which contains the amplified DNA, will form a micelle near the meniscus. The micelle can be transferred to a fresh tube with an automatic micropipette.

For many purposes, for example, purification of the amplified DNA using a Centricon microconcentrator or cloning amplification products, it is desirable to remove the oil from the sample before proceeding.

Do not attempt chloroform extractions in microtiter plates. The plastic used in these plates is not resistant to organic solvents.

\section{TROUBLESHOOTING}

Problem (Step 5): There is no amplified product.

Solution: It is likely that there was an error in assembling the PCR or programming the thermal cycler, or in the method used to detect amplified DNA. Try one or more of the following:

- Check reagents by setting up a control PCR with a new set of templates and reagents. Use a template and a set of primers that has worked previously for you or someone else.

- Use primer design software to check the primer specifications. If necessary, redesign the primers.

- Check that the temperature and cycle times are correctly programmed into the thermal cycler.

- Make sure to include samples of control DNAs on the gel used to analyze the product of the PCR.

- Check that the template DNA is not degraded.

Problem (Step 5): There is no amplified product-the target sequence for one or both primers is not present in the template DNA.

Solution: Check that the correct sequence was used to synthesize the primers and that the primers are complementary to the correct strands of the template DNA.

Problem (Step 5): There is poor yield of amplified product because of incorrect annealing temperature. Solution: Program the thermal cycler to run a temperature gradient in $2^{\circ} \mathrm{C}$ increments.

Problem (Step 5): There is poor yield of amplified product because of an insufficient number of PCR cycles.

Solution: Run the samples for an extra five cycles. When total mammalian DNA is used as template, it can be necessary to set up a reamplification reaction in which the product of a first round of PCR is used as the template in a second round.

Problem (Step 5): There is poor yield of amplified product because of incorrect $\mathrm{MgCl}_{2}$ concentration. 
BOX 1. VERIFYING AND PURIFYING THE AMPLIFIED PRODUCTS OF POLYMERASE CHAIN REACTIONS

If all has gone well during a PCR, virtually all of the dNTPs and primers present at the start of the reaction will have been incorporated into a single amplified product. In ideal circumstances, it might not be necessary to purify the amplified DNA before using it as a template (e.g., in sequencing reactions). Diluting the PCR 10- to 20 -fold can be sufficient to reduce the interference that low residual levels of primers or dNTPs can cause. However, to increase the chances of success in sequencing reactions, it is better to take steps to eliminate residual primers, dNTPs, single-stranded DNAs, and Taq polymerase, and to verify that the correct amplified product is sequenced.

\section{Verifying the Amplified Product of PCR}

Analyze a sample of the amplified DNA by agarose gel electrophoresis. Ideally, only one band of DNA should be visible after staining. If more than one band is present, choose one of the following options:

1. Repeat the PCR using a combination of touchdown and hot start (see Protocol: Hot Start Polymerase Chain Reaction (PCR) [Green and Sambrook 2018a] and Protocol: Touchdown Polymerase Chain Reaction (PCR) [Green and Sambrook 2018b]). If this is not successful, try increasing the temperature of the annealing step of the PCR until a single PCR product is obtained.

or

2. Cut out the bands of DNA separately, recover the DNAs from the gel slices, and reamplify them, using nested primers, if possible. An easy way to recover bands of DNA for reamplification is to dry the surface of the stained gel with Whatman 3MM paper and to stab a band of DNA with a hypodermic needle. The hypodermic needle is then quickly dipped into a fresh PCR mixture and agitated. The amount of DNA transferred is tiny but is nevertheless sufficient to serve as template in another round of PCR (Bjourson and Cooper 1992).

If multiple bands are again generated, recover the largest band of DNA and verify its sequence.

3. If neither of the above options works, the best course of action is to recover all of the bands from the gel and clone them individually (e.g., in a TA vector) (see below).

\section{Cleaning Up the Amplified Product of PCR}

Taq DNA polymerase has been reported to survive extraction with phenol:chloroform, ethanol precipitation, and other regimens commonly used to purify the products of PCRs (Crowe et al. 1991; Barnes 1992). However, a variety of commercial products are available to eliminate unconsumed dNTPs, single-stranded DNAs, and primers and to free the amplified DNA of thermostable polymerase in preparation for cloning and/or DNA sequencing. Commercial kits for PCR clean-up are reasonably priced and will be the least expensive option for most laboratories.

Kits in several different formats are available. Some examples follow.

1. DNA is bound to a silica surface, washed, and then eluted. Popular commercial kits include the QIAquick DNA Purification Kit (QIAGEN), the StrataPrep PCR Purification Kit (Agilent), and the GenElute PCR Clean-Up (Sigma-Aldrich).

2. DNA is bound to magnetic beads with anion-exchange capability, for example, ChargeSwitch-Pro PCR Clean-Up (Thermo Fisher Scientific).

3. DNA is purified through centrifuge columns in micropipette tips packed with a weakly anionic silica, for example, TopTIP charged with PolyWAX LP (GlySci, Glygen Corp.)

Solution: Using a $10 \times$ amplification buffer lacking $\mathrm{MgCl}_{2}$, optimize $\mathrm{Mg}^{2+}$ concentration by setting up a series of PCRs containing various concentrations of $\mathrm{Mg}^{2+}$ (e.g., $1.5-5.0 \mathrm{~mm}$ in $0.5 \mathrm{~mm}$ increments).

Problem (Step 5): There is poor yield of amplified product because of degraded dNTPs or an excessive amount of dNTPs in the reaction mixture.

Solution: dNTP solutions are very sensitive to repeated cycles of freezing and thawing. Set up control reactions with old and new batches of dNTPs. Excessive amounts of dNTPs can inhibit PCRs. 
Problem (Step 5): There is poor yield of amplified product because of a too-short extension time.

Solution: Extension time (in minutes) should be approximately equal to the size of the amplicon (in kilobases).

Problem (Step 5): There is poor yield of amplified product because of incorrect denaturation time or insufficient Taq DNA polymerase.

Solution: Ensure that the denaturation time is $2 \mathrm{~min}$, and use a fresh batch of Taq DNA polymerase.

Problem (Step 5): There is poor yield of amplified product because of insufficient template or degraded template.

Solution: Check the concentration and integrity of template DNA by gel electrophoresis.

Problem (Step 5): There is poor yield of amplified product because of sample evaporation.

Solution: Check that the caps of reaction vials are tightly closed and that the lid of the thermal cycler is sealed. If using plates, check the levels in the wells after a test run. Ensure that the screw-down lid of the cycler is pressed to the plate. Use rigid, purpose-made plates.

Problem (Step 5): There is poor yield of amplified product because of primer dimer formation. Solution: Try one or more of the following.

- Use primer design software to check the primer specifications. If necessary, redesign the primers.

- Increase the annealing temperature and/or decrease the concentration of $\mathrm{Mg}^{2+}$ in the reaction.

- Make sure that the concentration of primers in the PCR is between 0.1 and $1 \mu \mathrm{M}$.

Problem (Step 5): There is poor yield of amplified product because of impure template DNA. Solution: When setting up PCRs, ensure that no ethanol is present in the template DNA.

Problem (Step 5): There is poor yield of amplified product because of a high degree of secondary structure in the template DNA.

Solution: Use a hot start Taq DNA polymerase (see Protocol: Hot Start Polymerase Chain Reaction (PCR) [Green and Sambrook 2018a]) or touchdown PCR (see Protocol: Touchdown Polymerase Chain Reaction (PCR) [Green and Sambrook 2018b]).

Problem (Step 5): There is poor yield of amplified product because of a template rich in GC residues. Solution: Use a hot start Taq DNA polymerase (see Protocol: Hot Start Polymerase Chain Reaction (PCR) [Green and Sambrook 2018a]), touchdown PCR (see Protocol: Touchdown Polymerase Chain Reaction (PCR) [Green and Sambrook 2018b]), or an additive such as betaine or dimethyl sulfoxide.

Problem (Step 5): There is poor yield of amplified product because the ratio of target DNA:burden DNA is too high or too low.

Solution: In complex DNAs such as total mammalian genomic DNA, the ratio of target DNA:burden DNA can be as low as 1:107. It might be necessary to use the amplified product from a first round of amplification as template in a second.

Problem (Step 5): There is poor yield of amplified product because the ratio of primers:target DNA is suboptimal. 
M.R. Green and J. Sambrook

Solution: Primers are generally used in PCRs at a concentration between 0.1 and $1 \mu \mathrm{M}$. Using higher concentrations can lead to primer dimer formation, whereas lower concentrations might not be adequate if the amplicon is very small $(<100 \mathrm{bp})$.

Problem (Step 5): There are many short-sized, strongly amplified products (primers can amplify repeated sequences in the template DNA).

Solution: Use BLAST (http://www.ncbi.nlm.nih.gov/BLAST/) to align the primer sequences with the template DNA. If necessary, change the primers.

Problem (Step 5): There are many short-sized, strongly amplified products because reaction conditions are suboptimal.

Solution: Deficiencies of many kinds can generate this result. Possible remedies include one or more of the following:

- increasing the annealing temperature, the annealing time, the extension time or the extension temperature

- reducing the number of PCR cycles to minimum

- adjusting the concentration of $\mathrm{KCl}$ to $70-100 \mathrm{~mm}$ and adjusting the concentration of $\mathrm{MgCl}_{2}$ to $1.75 \mathrm{~mm}$

- decreasing the amounts of primers, template DNA, or Taq polymerase

Problem (Step 5): Products of many different sizes form a smear on the gel, indicating that concentrations of primers, Taq polymerase, or template are too high.

Solution: Set up a series of PCRs containing progressively lower concentrations of primers and/or progressively lower amounts of Taq polymerase.

Problem (Step 5): Products of many different sizes form a smear on the gel, indicating nonspecific annealing of primers.

Solution: Use hot start DNA polymerase.

Problem (Step 5): Products of many different sizes form a smear on the gel, indicating that the concentration of $\mathrm{Mg}^{2+}$ is not optimal.

Solution: Optimize $\mathrm{Mg}^{2+}$ concentration by running a gradient in $0.5 \mathrm{~mm}$ increments (1.5-5.0 mM).

\section{RELATED INFORMATION}

For further general advice on optimization and troubleshooting in PCR, see Cha and Thilly (1993), Roux (2003), and Rådström et al. (2003).

\section{REFERENCES}

Barnes WM. 1992. The fidelity of Taq polymerase catalyzing PCR is improved by an N-terminal deletion. Gene 112: 29-35.

Bjourson AJ, Cooper JE. 1992. Band-stab PCR: A simple technique for the purification of individual PCR products. Nucleic Acids Res 20: 4675.

Cha RS, Thilly WG. 1993. Specificity, efficiency, and fidelity of PCR. PCR Methods Appl 3: S18-S29.
Chiang CM, Chow LT, Broker TR. 1993. Identification of alternatively spliced mRNAs and localization of $5^{\prime}$ ends by polymerase chain reaction amplification. Methods Mol Biol 15: 189-198.

Crowe JS, Cooper HJ, Smith MA, Sims MJ, Parker D, Gewert D. 1991. Improved cloning efficiency of polymerase chain reaction (PCR) products after proteinase K digestion. Nucleic Acids Res 19: 184. 
Ferguson WJ, Braunschweiger KI, Braunschweiger WR, Smith JR, McCormick JJ, Wasmann CC, Jarvis NP, Bell DH, Good NE. 1980. Hydrogen ion buffers for biological research. Anal Biochem 104: 300-310.

Good NE, Winget GD, Winter W, Connolly TN, Izawa S, Singh RM. 1966. Hydrogen ion buffers for biological research. Biochemistry 5: 467-477.

Green MR, Sambrook J. 2018a. Hot start polymerase chain reaction (PCR). Cold Spring Harb Protoc doi: 10.1101/pdb.prot095125.

Green MR, Sambrook J. 2018b. Touchdown polymerase chain reaction (PCR). Cold Spring Harb Protoc doi: 10.1101/pdb.prot095133.
Rådström P, Löfström C, Lövenklev M, Knutssen R, Wolffs P. 2003. Strategies for overcoming PCR inhibition. In PCR primer: A laboratory manual, 2nd ed. (ed. Dieffenbach CW, Dveksler GS), pp. 149-161. Cold Spring Harbor Laboratory Press, Cold Spring Harbor, NY.

Roux KH. 2003. Optimization and troubleshooting in PCR. In PCR primer: A laboratory manual, 2nd ed. (ed. Dieffenbach CW, Dveksler GS), pp. 35-42. Cold Spring Harbor Laboratory Press, Cold Spring Harbor, NY. 


\section{The Basic Polymerase Chain Reaction (PCR)}

Michael R. Green and Joseph Sambrook

Cold Spring Harb Protoc; doi: 10.1101/pdb.prot095117

\begin{tabular}{|c|c|}
\hline $\begin{array}{r}\text { Email Alerting } \\
\text { Service }\end{array}$ & Receive free email alerts when new articles cite this article - click here. \\
\hline $\begin{array}{r}\text { Subject } \\
\text { Categories }\end{array}$ & $\begin{array}{l}\text { Browse articles on similar topics from Cold Spring Harbor Protocols. } \\
\text { Amplification of DNA by PCR (85 articles) } \\
\text { Molecular Biology, general (1293 articles) } \\
\text { Polymerase Chain Reaction (PCR) (139 articles) } \\
\text { Polymerase Chain Reaction (PCR), general (184 articles) }\end{array}$ \\
\hline
\end{tabular}

